UNIVERSITY OF CHITRAL JOURNAL OF LINGUISTICS AND LITERATURE

VOL. 5 | ISSUE I | JAN - JUNE | 2021 ISSN (E): 2663-1512, ISSN (P): 2617-3611

Preparing for War or Peace: Exploring the Peace Values in $9^{\text {th }}$ Grade English Textbook in Khyber Pakhtunkhwa

\author{
Kaukab Saba \\ Ph.D. Scholar, Air University, Islamabad \\ Kaukab.saba@iiu.edu.pk \\ Dr. Sadia Irshad \\ Assistant professor, Air University, Islamabad \\ Sadia.irshad@mail.au.edu.pk \\ Dr. Wasima Shehzad \\ Professor, Air University, Islamabad \\ wasima@mail.au.edu.pk
}

\begin{abstract}
Out of many other global issues, one of the most threatening to human beings is war and conflict. Making this world a peaceful abode is the objective of many institutions and Education is one of them. Language teaching can serve as a very effective tool to inculcate peace among the students who build a peaceful nation in return. The study aims to explore the elements of peace values in English textbooks of grade $9^{\text {th }}$ taught in schools of Khyber Pakhtunkhwa. Textbooks are not only used for transferring knowledge of the respective subject but also to bring social reformation to society. The study is qualitative in nature and falls under the constructivist paradigm. The study can be significant for curriculum developers, textbooks writers, teachers, and students to make them aware of the importance of peace development through textbooks. The study followed the theoretical framework of Balasooria (2011) to identify peace values. The findings have shown that social peace value is the most dominant in use in the textbook besides other categories, inner peace, and peace for nature. Moreover, the analysis has revealed that addressing issues like human rights awareness, gender equality, and mental health is lacking in the text which can become a reason for conflict and restlessness in the society eventually leading to a threat to the peace of the society.
\end{abstract}

Keywords: Textbook, Peace, Peace Values, Khyber Pakhtunkhwa

\title{
Background of the Study
}

As a repercussion of 9/11, U.S allied forces invaded the next-door western neighbor of Pakistan, Afghanistan. These incidents drastically changed the sociopolitical scenario of the whole region including the security dynamics of Pakistan. As a result, Pakistan paid the worst in the form 
UNIVERSITY OF CHITRAL JOURNAL OF LINGUISTICS AND LITERATURE

VOL. 5 | ISSUE I | JAN - JUNE | 2021

of suicide attacks as well as drone attacks. During the last eleven years over three hundred and twenty suicide attacks killed nearly forty thousand innocent people (Hassan et al, 2014). Many extremist groups in the territory of FATA, Khyber Pakhtunkhwa (KP) Tribal areas, Karachi and Quetta, trained uneducated or poor-educated lads in their radical belief system which was rejected by almost all the religious clerics categorically and unanimously. Those young boys were misused and misguided by providing them manipulative literature to make them a softer tool for protestors to carry out their terrorist accomplishments. If these suicide bombers were provided with good education and awareness, the chances of the insurgent activities could have been minimized.

Out of the many goals of our national education policy (2017-2025), the very first one is character-building which encompasses Taleem (Seek, Use and Evaluate Knowledge), Tarbiyya (Social, Technical, Moral and Ethical Training), and Tazkyya (Purification of Soul) and in the contemporary era, the latter two goals need to be emphasized to bring a positive change in the personality of the students. Article 26 of the Universal Declaration of Human Rights defines education as "Education shall be directed to the full development of the human personality and the strengthening of respects for human rights and fundamental freedoms" (Assembly. U.G, 1948).

Many efforts have been made for "education for all" but more important is to consider "education for what," Keeping into consideration the contemporary social circumstances, the concept of peace needs to be emphasized further in the curriculum to orient the process towards broader social good. Peace can be defined as understanding religion and cultural diversities, resolving personal as well as global conflicts, and clarifying moral and ethical values.

Terrorism and fundamentalism is global issue and it is the priority of every nation's policy to counter these issues in the contemporary era, the international organizations, United Nation, UNESCO, and many got active to solve the problem of war and conflict and hence started peace education programs across the globe. One example in this regard is the peace education program arranged by the UN in schools at Lyari in Karachi. Such programs have been proved more effective than anticipated. These programs addressed issues like extremism, terrorism, and peace promotion. Such programs bore fruits in the form of making the participants of the research more tolerant and peace-loving than before. But to attain viable peace in the long term, the school curriculums, books, and teaching methodology need to be designed peace-oriented. 
UNIVERSITY OF CHITRAL JOURNAL OF LINGUISTICS AND LITERATURE

VOL. 5 | ISSUE I | JAN - JUNE | 2021

Education for peace has been named with various titles for a long i.e. social justice education, peace education, human rights education, etc. Peace education, according to UNICEF, is education that promotes the skills, knowledge, attitudes, and values to bring about behavior change in individuals to prevent violence and conflict, to resolve conflict, and to create conditions supportive of peace (Fountain, 1999). Peace education can not only be taught as a separate subject but also as a basic ideology integrated into the overall curriculum.

According to National Education Policy 2018, presently three schooling systems are working in Pakistan i.e. Government schools, Private schools, and the Madrassa system. Since the majority of students at the primary level (i.e. $73 \%$ ) are enrolled in government schools (26\% in private schools and only $1 \%$ in Madrassa), the main focus of this research will be the government school curriculum.

The current research aims to analyze the elements of peace in textbooks of English subjects taught at the secondary level i.e. grade $9^{\text {th }}$ in Khyber Pakhtunkhwa. Besides, the research aims to analyze how peace education has been addressed in the linguistic contents of secondarylevel English textbooks. Love for peace can be inculcated among students through variant agents, for example, textbooks, role play, games, and collaborative learning, etc. Furthermore, the research will help the students in developing their critical thinking so that they may differentiate between war and peace. Keeping in mind the aims of the research, the following research questions have been designed:

1. How textbooks of English in KP Schools at the secondary level (to what extent) are Peace centric?

2. How selected textbooks negate violence and wars and promote Peace and Compassion?

3. How are the language of Peace linguistics and relevant content practiced for teaching English to describe Peace/conflict?

4. What different peace values can be found in the textbook of English for 9th -grade and which is the dominant one?

\section{Literature Review}

Language is a means through which we not only communicate our ideas but can also bring ideological and social change. A major tool for bringing any sociological change is language. 
UNIVERSITY OF CHITRAL JOURNAL OF LINGUISTICS AND LITERATURE

VOL. 5 | ISSUE I | JAN - JUNE | 2021

The more popular a language is, the wider and stronger will be the impact of ideas that are disseminated through that specific language. English, the most global language of today's world, can play a major role in bringing positive change in society. It is used to communicate between countries.

In a globalized world, social interaction is not only occurring within local networks but increasingly within non-local networks owing to ever-improving communication technology. To be able to communicate effectively within non-local networks, language becomes an issue of practical importance. (Kruger 2012)

Teaching is a very sacred profession because teachers not only give knowledge about the concerned subject which they teach, but they enable the students to become social-change makers. TESOL is not merely about teaching and learning grammatical terms, reading, listening, or writing; rather it can be exploited to create social awareness as well. Indeed, teachers can be a major source in spreading positive changes to their society. As discussed by Freire (2013) teachers have an important job to raise students' critical consciousness of their world. While teaching language, the teacher has the choice to select material from a wide range of topics so they must select the topics which address the topics of global issues like global warming, gender equality, ethics, and civic values. In this way, besides learning English, students may also learn good values. If the teachers address these issues in the class and create awareness about how to respect the difference of opinion of others it will lead to a positive and peaceful society. English is a global language so the teaching materials about global issues like peace, freedom, human rights, or environmental problems will bring students into the new learning practice. Out of many social issues, one of the most threatening social concerns is the growing war and terror in the world which has replaced peace and harmony. Professionals from all walks of life are striving to promote peace development but teachers can play a major role in this domain. Being social animals and to survive in society, humans have to make the place where they live a peaceful home. Peace and serenity are necessary since it becomes human rights issue. Kruger (2011) has explained the responsibilities of TESOL teachers to promote peace in the society and he also highlights that teachers must be integrated into creating social awareness through the selected material for language teaching. Larson (1990), a communication specialist, has also advocated that teachers should be at the 
UNIVERSITY OF CHITRAL JOURNAL OF LINGUISTICS AND LITERATURE

VOL. 5 | ISSUE I | JAN - JUNE | 2021

forefront to promote peace which is one of the serious globally threatening issues. But unfortunately, the teachers are not trained enough to perform their roles effectively in this regard as McInnis and Well (1994) have stated that TESOL teachers are not playing their central role in peace education rather they are in the periphery in this realm.

The notion of the classroom as a non-threatening setting is based on the premise that Dewey (1966) states "Classroom is a microcosm of society" (p.93). And the acknowledgment and investigation of social problems and disorders to learning in the "safe environment" of the classroom will endorse the development of peace among the students, especially when it is a language class, we can use any of the skills to promote peace.

Reading is one of the most important skills in language learning. This skill can also be used to promote peace among the students. Koda (2005:4) has explained that when a reader combines what he reads with his already known knowledge that is when reading comprehension occurs. So the reading text given to students must be worth enough to bring social reforms in the world hence they will not only learn a language but also serve humanity.

Monitor Theory by Stephan Krashen postulates that:

Acquisition and learning are used in very specific ways. Normally, acquisition "initiates" our utterances in a second language and is responsible for our fluency. Learning has only one function, and that is as a Monitor or editor. Learning comes into play only to make changes in the form of our utterance after it has been "produced" by the acquired system (Krashen, 1982, p.15).

This shows that already existing knowledge is useless unless stimulated by the learning process. Thus, the imprinting of tabula rasa is not the function of acquisition but proper learning that is done through various techniques used to improvise the process. The purpose of teaching reading skills may also be turned into promoting peace among the students in the classroom.

Textbooks are designed to teach the students regarding their context. In textbooks, the syllabus and chapters have a great impact on students. A textbook is a book used for the study of the subject and academic topics in school, university, or college. Textbooks are a rich source to examine different components. There are many studies conducted on the evaluation of the 
UNIVERSITY OF CHITRAL JOURNAL OF LINGUISTICS AND LITERATURE

VOL. 5 | ISSUE I | JAN - JUNE | 2021

textbooks to analyze various elements. Peace can be a strong element to analyze in textbooks to study its impact on students who can be a strong source to disseminate it further in society.

Peace is a notion of mutual relationship and agreement sustaining in the absence of any conflict or violence. Peace is of two types i.e. negative peace and positive peace. Negative peace is the absence of war, a state of affairs that is sought through diplomacy and negotiation (Galtung, 1967). Positive peace is achieved through the promotion of fair social conditions and structures and relies on respect for human rights, ecological concerns, education, and economic wellbeing as stated by Barash and Webel (2007). There are multiple ways of promoting peace and education is one of the major sources through which we can endorse it.

In Pakistan, there are three schooling systems i.e. Government, private, and Madrassah. The report of the 9/11 Commission stated that in 2009 that in some Madrassah served as 'incubators for violent and extremism' that encourages students to do jihad and other wars. There is also some text which encourages students to be against India. There is a need to revise the curriculum to enable the students to contribute to the peace and happiness of the country.

In foreign language classes, the course content will naturally be in the target language, which means that learners will acquire information in a language other than their own. This, alone, may be said to create an international consciousness because foreign language courses are essentially expected to have a global spirit denoting that violence "is disintegrative, while nonviolence is integrative power" (Nagler, 2004, p. 43). Through this education, students may be trained as global citizens and see the relationship between who they are and what they do in the global environment (Hettler \& Johnston, 2009, p. 106). Classrooms can serve as a better and more productive place for bringing social reforms such as peace. Bajaj (2013) outline the education is classrooms consideration and offers genuine prospects:

Peace education is not just about the elimination of violence, although that is a central tenet, but also about creating preventive structures and conditions that better align educational policies, pedagogies, and content toward peace, social justice, and human rights principles. As such peace education can be understood as a harmonizing integrative force used to establish both common grounds and affirm diversity in plural contexts. It can and should be promoting positive change, beyond the absence of direct and indirect violence. (p. 141) 
UNIVERSITY OF CHITRAL JOURNAL OF LINGUISTICS AND LITERATURE

VOL. 5 | ISSUE I | JAN - JUNE | 2021

\section{Previous Studies on Evaluating Peace values in School Textbooks}

Many researchers have been conducted in this regard. Finch (2004) conducted research named Peace Begins in the classroom in which he emphasized the need of a peaceful environment. Further, he proved that reading material can help a lot in achieving the goal. Our research is an attempt to examine to what extent the textbooks used in Khyber Pakhtunkhwa at the secondary level are peace centric.

Hymel and Darwich (2018) conducted research to show how education helps build peace. Their work has promoted that Social and Emotional Learning (SEL) can help promote peace and other pro-social elements among the students. This research has a similarity with our research in that it focuses on peacebuilding through various strategies in the classroom such as problemsolving etc. Our research also focuses on the encouragement of peace through teaching the English language in the classroom by using textbooks.

Gebregeorgis (2016), analyzed the English Textbook written for Ethiopian students of grade $9^{\text {th }}$ to find out the values and prejudices and explored the extent to which the textbook is peace-centric. He applied textual, contextual, and sociological discourse analysis to the study by applying the theoretical framework of Balasooriya (2011). The findings of the study revealed that inner peace, sociological peace, and peace with nature are incorporated but it had the elements of gender stereotyping which lead to the restlessness of the society. Kruger (2011) conducted his study about English as the language of the globe and measured the potential of this language teaching to disseminate the social reformations that it can bring through TESOL. The context of the study was South Africa. Similarly, Wulandari and Murdiono (2018) also held a study to explore the peace values in Pancasila and Civic Education textbooks in Senior High School in Indonesia and their findings showed the presence of peace values. Bentrovato and Nissanka (2018) also researched the civics textbooks that were provided by the donors in Sri Lanka during the civil war and the findings proved that the textbooks contained elements of social construct and social cohesions to avoid civil disobedience in the state. Moreover, Shuayb (2015) in Lebanon analyzed civics textbooks and Darweish and Mohammed (2017) investigated the content of History Education (HE) textbooks at the primary level in Indonesia, to analyze the peace education values integration in the text. Likewise, Ide, Kirchheimer, and Bentrovato's (2018) contribution in this domain cannot be ignored, who identified peace and conflict contents in school textbooks. 
UNIVERSITY OF CHITRAL JOURNAL OF LINGUISTICS AND LITERATURE

VOL. 5 | ISSUE I | JAN - JUNE | 2021

To conclude, from these articles reviewed, it is revealed that there is no study of peace linguistics in the English language in a nonnative context conducted in Pakistan. It means that the peace values represented in English textbooks in Pakistan have never been investigated by researchers and the current research will be an initiative in this regard. Hence, peace linguistics is an emerging discipline and in collaboration with peace education, it has the potential to bring many social reforms in the society to combat war and terror and sustain peace of the world.

\section{Research Method}

The current research falls under the paradigm of the interpretive paradigm and is constructivist in nature. Since the research has followed Sociological discourse analysis so the study has adopted qualitative research methodology. McEnery and Wilsonis (2001) explain qualitative analysis as the most suitable to recognize and define aspects of language use. Moreover, Ruiz (2009) has declared sociological discourse analysis as qualitative and it sticks to the textual, contextual, and sociological levels of analysis.

\section{Rationale and Delimitations of the Study}

The 9th grade English textbook taught in Government schools of Khyber Pakhtunkhwa was selected for data analysis. The rationale behind selecting textbooks from government schools is the data collected through National Education Policy 2018. According to the report, three streams of education are running: government $73 \%$, Private $26 \%$, and Madrassa $1 \%$. Hence the highest rate of enrolled students is in a government school. Furthermore, the secondary level has comparatively greater intellectual maturity to the primary level for peace development among the students because high school textbooks are prepared at the national level (Gebregeorgis, 2016). Khyber Pakhtunkhwa is the most affected region by the war on terror and suicide bombing in this region is reported greater as compared to other provinces (Nadia, 2013) that is why the study was delimited to this domain.

The title of the book is "A Textbook of English Grade $9^{\text {th }}$ Khyber Pakhtunkhwa Textbook Board Peshawar. The book has followed National Curricula 2006 and it is the revised edition with some changes (when revised) with new essays, stories, poems, fresh layout, and designs. The total number of pages in the book is 152 and there are 15 Chapters/Units in the book. The chapters, along with the themes, are mentioned on the content page. Only the chapters were taken into 
UNIVERSITY OF CHITRAL JOURNAL OF LINGUISTICS AND LITERATURE

VOL. 5 | ISSUE I | JAN - JUNE | 2021

consideration for the analysis (exercises and question answers are exempted). The selected textbook was used for the analysis to explore to what extent and how peace values are integrated.

English Textbooks have the potential to bring social reform and they can be a great source to promote peace ethics and bring about peace centric changes in the behaviors of learners as stated by Gabregeorgis (2016) “Textbooks are not only meant to deliver subject knowledge; they are also a medium to convey universal and community-specific values"(Abstract). If a Peace centric syllabus is implemented through ELT (English Language Teaching), students' minds will be able to generate peaceful ideas. However, there is no such study conducted earlier to explore the extent to which peace linguistics is incorporated in English textbooks in Khyber Pakhtunkhwa

Pakistan's Ministry of Education, National Curriculum wing authorized and Khyber Pakhtunkhwa published English curriculum, which is taught in all government schools, is following theme-based language syllabus (a communicative teaching strategy recommended by CEFR)

\section{Theoretical Framework}

The theoretical framework selected for the current research is presented by Balasooriya (2001,10-11). According to this theory, peace is the combination of inner peace, social peace, and peace with nature. Gebregeorgis (2016) has used the tri-phase analytical framework of Balasooriya (2001) in his work and also mentioned the categorization of the elements of peace by Balasooriya into the following categories:

Inner Peace: harmony and peace with oneself, good health and absence of inner conflict, joy, sense of freedom, insight, spiritual peace, feelings of kindness, compassion and contentment, appreciation of art.

Social Peace: peace between man and man (men and women as well!), harmony arising from human relationships at all levels, conflict reconciliation and resolution, love, friendship, unity, mutual understanding, acceptance, cooperation, brotherhood, tolerance of differences, democracy, community-building, human rights, and morality.

Peace with Nature: harmony with the natural environment and Mother Earth" (p. 10-11)

The analysis of the text was conducted at three levels; textual level, contextual level, and sociological level. In the first part, the text was analyzed at the textual level, the text was read 
UNIVERSITY OF CHITRAL JOURNAL OF LINGUISTICS AND LITERATURE

VOL. 5 | ISSUE I | JAN - JUNE | 2021

many times and content analysis was conducted. Moreover, thematic coding was done manually keeping in mind the categories, inner peace, social peace, and peace with nature, of the selected theoretical framework of the study.

As the research is an attempt to do sociological discourse analysis so in the second phase the data were analyzed in the context in detail to know "who is saying what" and to study the intentions behind the discourse creators. Moreover, at the sociological level, the textual and contextual results were knitted to highlight the social circumstances in which the text was produced.

\section{Analysis}

The peace values in the text were explored following the categorization of Balasoorya (2001) inner peace, social peace, and peace for nature. I thematically coded the text under the above-mentioned peace values categories given by Balasoorya. Inner peace is identified through exploring positive self-concept, good health/patriotism, Compassion; social peace is identified through tolerance, solidarity, social responsibility, patriotism, and respect for life in all its forms. Peace through nature aims at studying nature and environmental care.

The very opening of the book has a content page that contains chapters' names and their themes. It is important to share the names of the chapters and their themes for a detailed analysis of peace contents within the chapters because even the titles are telling half of the story that I will explain later in the analysis part.

Following are the names of the chapters along with their themes.

1. Hazrat Muhammad the Model of Tolerance

Tolerance

2. Iqbal's Message to Youth

patriotism

3. Quaid-A Great leader

Role model

4. The Daffodils

Nature Poem

5. The Madina Charter

Harmony/Peaceful co-existence

6. Nasiruddin

Humour

7. The Two Bargains

Justice

8. Hope is the Thing with Feathers

Poem on the life skills of education

9. The Fantastic Shoemaker

Dignity of Labour

10. Technology in Everyday life

Technology 
UNIVERSITY OF CHITRAL JOURNAL OF LINGUISTICS AND LITERATURE

VOL. 5 | ISSUE I | JAN - JUNE | 2021

11. Safety first

12. The old woman
Crisis management

Humanity

It is evident from the titles of the chapters and their themes that inner peace, social peace, and peace for nature are incorporated in the book. The detailed analysis will further enhance the point and strengthen my argument further. The above-mentioned three categories inner peace, social peace, and peace nature were identified in the text one by one.

Inner peace can be in the form of positive self-concept, good health, and compassion. Starting from the inner peace content in the English textbook of grade $9^{\text {th }}$ has shown its instances in the form of positive self-concept and to foster learners' positive self-concept exuberant examples of personalities like Hazrat Muhammad PBUH, Allama Iqbal, Quaid-E-Azam, Hazrat Usman Ghani (RA), Hazrat Umer (RA) are given. All these are role models for Muslims and their major contribution in terms of peace promotion in the society is inevitable to deny. They have remained icons for tolerance and peace. One way or the other they have worked for humanity and short stories from their life are shared in the chapters about them to motivate the students about their contribution as peace-makers in society. Moreover, the Mind map in the very first chapter is peace-related and it talks about the concept of our Holy Prophet Hazrat Muhammad SAW about peace. The main headings of the mind map are "Rahmatullil Alamein, Justice, Humanity, Patience and Sadiq and Ameen" (p.2). The whole chapter revolves around these points which nourish the learner's inner peace. Similarly, the Mind map (p.42) is all about tolerance and solidarity. This mind map is in the chapter titled The Madina Charter and the bullets of the mind map are Peaceful co-existence, religious harmony, humanity and justice, patience and tolerance, love and peace, and freedom and safety.

The textbook is full of peace and compassion-related words out of which few are quoted in the analysis. It has many examples of patience, kindness, forgiveness, tolerance, compassion, patience, the conquest of Makkah, the story of the Rabbi Zaid, the Abu Sufyan, tolerance towards Muslims as well as non-Muslims.

The chapter Safety first is all about how to handle heart attack, choking, burn, etc. the chapter details is an attempt to inculcate inner peace which can be achieved through sound health. 
UNIVERSITY OF CHITRAL JOURNAL OF LINGUISTICS AND LITERATURE

VOL. 5 | ISSUE I | JAN - JUNE | 2021

Now moving towards the social peace categories_there are multiple pieces of evidence from the text which show the social peace values. The opening chapter of the text is about the theme of Tolerance (Ch. 1, 5, 7 ) and the very first line of the chapter is about the definition of peace. By tolerance, we mean a fair and objective attitude towards those whose lifestyle differs from ours (ch1.pg.2).

Moreover, the given lines from the text show that cultural and religious diversity is also addressed to some extent. He (PBUH) knew that tolerance was necessary when different communities lived together (ch.5.pg.42). The major concern of social peace is to promote solidarity and the selected text has multiple shreds of evidence of Solidarity $(\mathbf{C h} . \mathbf{1}, \mathbf{2}, \mathbf{3}, \mathbf{7}, \mathbf{1 5})$. Furthermore, the role models are described to show the elements of solidarity as Hazrat Muhammad (PBUH) granted general amnesty to the entire population of Makkah (ch. 1.pg.3). Similarly, the lines which say you may belong to any religion or caste ----we all are citizens of one caste (ch.3.pg.27). Here in these lines, the rights of minorities are explicitly shown which leads to peace and harmony. Mind map (pg42) is also an example of solidarity and it shows how important it is to respect the opinion of others to show solidarity and sustain peace.

Social responsibility $(\mathbf{C h . 1 4 , 1 5 )}$ is another most important aspect of social peace, the text has some examples of exhibiting social responsibility. I pray thee, then, Write me as one that loves his fellow-men (Ch.14.pg.148). Another example: It is high time that we can act now otherwise the biodiversity will vanish. (ch.15, pg138). Similarly, Patriotism (Ch.2, 3, 7,) and Pakistan zindabad, Pakistan Zindabad, (Ch3, pg.25) are other few examples to disseminate the sense of social responsibility.

Inner peace cannot be achieved if peace for nature is ignored because peace is not only about being compassionate and kind enough to other human beings but also towards mother earth. Peace with nature is all about the environmental care that we show towards animals, plants, and the entire planet earth. It deals with creating awareness about the environment-friendly steps as well as the endangered species in the world. In the current book, there are two chapters about nature, Daffodils, and Biodiversity in Pakistan. In the earlier chapter beauty of nature is addressed to inculcate a love of nature among students. On the other hand, the later chapter has tried to cover the biodiversity in Pakistan, as the title speaks itself. Unfortunately, this national heritage is 
UNIVERSITY OF CHITRAL JOURNAL OF LINGUISTICS AND LITERATURE

VOL. 5 | ISSUE I | JAN - JUNE | 2021

facing threat from a parasitic disease that needs to be cured (ch14, pg.137), this sentence is an example in this regard. The challenges faced by Pakistan in biodiversity are also highlighted in the said chapter as one of the pieces of evidences is Pakistan is facing challenges in biodiversity (ch14,pg138).

Peace is the combination of inner as well as outer peace, indeed peace starts and it grows outward. As stated by Gabrigorgeos (2016, p. 13)

The more one develops a positive self-concept, becomes healthier and compassionate, the better his or her inner peace will be. Similarly, a community can be more cohesive and harmonious if there is tolerance, solidarity, and a sense of social responsibility among its members. Fair and friendly biotic and abiotic relationships also lead to ecological peace. Inner peace, social peace, and peace with nature together yield holistic and sustainable peace.

The analysis of the book has shown the elements of all the three categories of peace given by Balasoorya (2001).

\section{Findings and Discussion}

The detailed analysis of the selected text has shown elements of peace inculcated in it in the form of role models, famous figures from history, usage of positive and peace-related words, and the themes of solidarity as well but it can be further enhanced by accommodating further themes, for example, cultural diversity, religious diversity, gender diversity, ethnic diversity, etc. Pakistan is a multicultural state where major four cultures, Panjabi, Sindhi, Baloch, and Pakhtun are living together. Creating awareness about respecting cultural diversity, locally and internationally, in the books can enhance the chance of peace promotion through textbooks. So, the first research question is answered by the analysis that the selected textbook has incorporated peace values superficially and too a little extent and there is still some room to make it more peacecentric.

Moreover, the analysis of the text has shown that not even single evidence of conflict and violation was observed in the text; rather the content is peace-relevant and promotes tolerance, compassion, and solidarity through the mouthpiece of successful heroes of history. Hence, the role models and stories from history have been incorporated to promote peace and compassion and negate war and conflict. 
UNIVERSITY OF CHITRAL JOURNAL OF LINGUISTICS AND LITERATURE

VOL. 5 | ISSUE I | JAN - JUNE | 2021

Moving towards the next research question about how the language of Peace linguistics and relevant content practiced for teaching English to describe Peace/conflict can be answered well through the opening lines of the first chapter of the selected textbook. The book starts with the definition of peace in the Islamic context because the people from the selected regions have an association with their religion. Hence, the linguistic contents have shown that the text has followed communicative dignity and communicative peace.

Finally, the analysis has proved that overall the three peace categories, by Balasooria (2011) inner, social, and nature are traced in the text but the most dominated category of peace values used in the textbook is social peace and it is an attempt to answer the last research question. The evidence from the text shows examples of solidarity, tolerance, and social responsibility from social peace.

The findings of the result show that the incorporation of peace value is observed, but to a little extent and it could be enhanced further if human rights and fundamental freedom would have been addressed. Article 26 of the Universal Declaration of Human Rights defines education as "Education shall be directed to the full development of the human personality and the strengthening of respects for human rights and fundamental freedoms" (Assembly. U.G, 1948). No such stance has been observed in the entire text to define what human rights and fundamental freedom is all about; there must be a separate chapter about it.

Similarly, the book has addressed the issues of religious freedom (pg 3 and18) to inculcate peace and tolerance, as it is believed that "education 'should promote understanding, tolerance, and friendship among all nations, racial or religious groups' (UN, 1948)." But, cultural diversity is not contextualized in the book. Although the examples from Islamic history through the mouthpiece of Hazrat Muhammad (PBUH), Hazrat Usman Ghani (RA), and Quaid-e-Azam are inspiring enough there should be chapters about how national, racial and cultural tolerance is important in sustaining peace. Pakistan is a multicultural country and in this situation, religious and cultural diversity becomes a reason for conflict so the book lacks examples from unity in diversity in this regard. No doubt, the referred role models are highly influential and cannot be compared but the text could contextualize the peace-centric values by adding a chapter about great Pakhtun leaders like Bacha Khan, who advocated peace in all walks of life. Uttaran, Ali, and 
UNIVERSITY OF CHITRAL JOURNAL OF LINGUISTICS AND LITERATURE

VOL. 5 | ISSUE I | JAN - JUNE | 2021

Ahmad (2019) inform about Bacha Khan and Gandhi "scholars opined that their pedagogies and lives (as model examples) have been consistently influencing and transforming people and communities, and in turn have abated conflicts and fostered peaceful and humane coexistence both locally and globally.

Moreover, the text lacks any instance of a female role model, entrepreneur, leader, etc. our history is full of female successful women, for example, Hazrat Fatima (RA), Fatima Ali Jinnah, but the text has not followed gender equality which may lead to propagating unrest in society. Gender-based conflicts are a continuous threat to the peace and harmony of Pakistani society. These conflicts have contributed a lot in generating an unending rivalry among men and women which further resulted in the marginalization of women, domestic violence, broken and fragmented social structure, intellectual emptiness in the coming generations, and loss of harmony and peace in the social system which is a vital element for the progress of a society.

Furthermore, there is only one chapter on health with no detail of what peace through mental health means because peace starts within, and the importance of Psychological health should have been incorporated to make students aware of physical as well as psychological health to enable them in a peaceful society. The requisite to integrate peace values in an education system requires improving teacher training, curricula, the content of textbooks ... to educate caring and responsible citizens open to other cultures, able to appreciate the value of freedom, respectful of human dignity and differences, and able to prevent conflicts or resolve them by nonviolent means. (UNESCO 1995)

The national education policy of Pakistan has the objectives of character building in the form of Tazkya and Tarabya (discussed in detail in the introduction) which proves that at the macro level the incorporation of character building objectives have been already added and directed the curriculum developers to include peace-related content in the curriculum but it needs to be properly addressed in the textbooks and classrooms as well by the textbook writers and teachers. The policy, curriculum, and textbooks are revised after some time in Pakistan to update but even the revised editions still have room to improve further. Pingel (2010) writes that "language textbooks and readers also contribute considerably to what students know and how they think about others" (p.8) 
UNIVERSITY OF CHITRAL JOURNAL OF LINGUISTICS AND LITERATURE

VOL. 5 | ISSUE I | JAN - JUNE | 2021

and this perception of the students can be developed in the way the teachers want because you become a person after twenty years what you read, listen, and live today.

\section{Conclusion}

The current research has theoretical, empirical, and practical contributions. The theoretical contributions of the current study have the potential of making and/or using the textbook as a tool for peace promotion. Moreover, the empirical contribution can be in the form of other researchers who may contribute in exploring peace linguistics in other levels such as primary, graduate, fiction, etc. lastly, the practical contribution can be on the part of; authors, to guide them to write peace centric textbooks; teachers, to arrange workshops for them to motivate and instruct them to teach and select peace centric contents; curriculum designers, to influence them to design peace-oriented curriculum; publishers, to inform them about the need of publishing preferring the books which have peace elements in it; students, to demand peace-related material in their ELT classrooms.

\section{References}

Assembly, U. G. (1948). Universal declaration of human rights. UN General Assembly, 302(2)

Bentrovato, D. \& Nissanka, M. (2018). Teaching Peace in The Midst of Civil War: Tensions between Global and Local Discourses in Sri Lankan Civics Textbooks. Global Change, Peace \& Security, 30(3), 353-372. Doi: 10.1080/14781158.2018.1505716

Balasooriya, A. S. (2001). Learning the Way of Peace: A Teachers' Guide to Peace Education. New Delhi: UNESCO.

Brantmeier, E. J., \& Bajaj, M. (2013). Peace education praxis: Select resources for educators and researchers. In Educating about Social Issues in the 20th and 21st Centuries: A Critical Annotated Bibliography. Vol. 2, edited by S. Totten and J. Pedersen. Charlotte, NC: Information Age.

Bretherton, D., Weston, J. \& Zbar, V. (2007). Peace education curriculum development in postconflict contexts: Sierra Leone.

Barash, P. D., \& W. P. Charles. (2014). Peace and Conflict Studies. 3rd ed. Los Angeles, CA: Sage.

Cates, K. (1990). Teaching for a better world: Global issues in language education. The Language Teacher, 14(5), 3-5. 
UNIVERSITY OF CHITRAL JOURNAL OF LINGUISTICS AND LITERATURE

VOL. 5 | ISSUE I | JAN - JUNE | 2021

ISSN (E): 2663-1512, ISSN (P): 2617-3611

Cates, K. A., \& Jacobs, G. (2006). Global issues projects in the English language classroom. In Project-based second and foreign language education: Past, present, and future (pp. 167180). Greenwich, CN: Information Age Publishing. Retrieved from https://www.academia.edu/3547747/Global_issues_projects_in_the_English_language_cl $\underline{\text { assroom }}$

Darweish, M. \& Mohammed, M. A. (2017). History Education in Schools in Iraqi Kurdistan: Representing Values of Peace and Violence. Journal of Peace Education. Doi: 10.1080/17400201.2017.1409198

Dewey, J. (1916/1966). Democracy and Education and Introduction to the Philosophy of Education. New York: Free Press. (First Published, 1916.)

Dutta, U., Ali, S. R., \& Ahmad, N. (2019). Relevance and Values of Gandhi's and Bacha Khan's Moral Education in Negotiating/Addressing Situated Disparities of South Asia. Education Sciences, 9(2), 108.

Fountain, S. (1999). Peace education in UNICEF. Unicef, Programme Division.

Freire, P. (2013). Education for Critical Consciousness. Bloomsbury Publishing.

Friedrich, P. 2007. Language, negotiation and peace: The use of English in conflict resolution. Great Britain: Continuum.

Gebregeorgis, M. Y. (2016). Peace Values in Language Textbooks: The Case of English for Ethiopia Student Textbook. Journal of Peace Education. Doi: 10.1080/17400201.2016.1228526

Galtung, J. (1967). Theories of Peace A Synthetic Approach to Peace Thinking. Oslo: International Peace Research Institute.

Gebregeorgis, M. Y. (2016). Peace Values in Language Textbooks: The Case of English for Ethiopia Student Textbook. Journal of Peace Education. Doi: $10.1080 / 17400201.2016 .1228526$

Hettler, S., and L.M. Johnston. (2009). Living peace: An exploration of experiential peace education, conflict resolution and violence prevention programs for youth. Journal of Peace Education, 6(3), 101-19. 
UNIVERSITY OF CHITRAL JOURNAL OF LINGUISTICS AND LITERATURE

VOL. 5 | ISSUE I | JAN - JUNE | 2021

Hymel, S., \& Darwich, L. (2018). Building peace through education. Journal of peace education, 15(3), 345-357.

Koda, K. (2005). Insight into second language reading. New York:Cambridege University Press

Kruger, F. (2011). The Role of TESOL in Educating for Peace. Journal of Peace Education, 9(1), 17-30. Doi: 10.1080/17400201.2011.62376

Kruger, F. (2012). The role of TESOL in educating for peace. Journal of Peace Education, 9(1), 17-30.

Krashen, S. (1982). Principles and practice in second language acquisition.

Larson, D. 1990. TESOL's role in global understanding: A possible agenda. TESOL Newsletter24, no. 1: 21.

McEnery, T., \& Wilson, A. (2001). Corpus Linguistics: An Introduction. Edinburgh: Edinburgh University Press.

Masoud-ul-Hassan, Shahzada\&Azhar, Tehseen\& Hassan, Taimoor. (2014). Educating Peace in Pakistan. Journal of Education and Practice. 5. 96-102.

Mclnnis, D.J., and B.J. Wells. 1994. Peace education and its role in the EFL classroom.Soka University Peace Research Institute Journal 16: 57-74.

Nagler, M. N. (2004). The Search for a Nonviolent Future: A Promise of Peace for Ourselves, Our Families, and Our World. Makawao, HI: Inner Ocean.

Ide, T., Kirchheimer, J. \& Bentrovato, D. (2018). School Textbooks, Peace and Conflict: An Introduction. Global Change, Peace \& Security, 30:3, 287-294. Doi: 10.1080/14781158.2018.150571.

Pratama, H., \& Yuliati. (2016). Global Education in English Classroom: Integrating Global Issues into English Language Teaching. International Journal of Social Science and Humanity, 6(9), 719-722. http://doi.org/10.18178/ijssh.2016.6.9.739

Shuayb, M. (2015). Human Rights and Peace Education in the Lebanese Civics Textbooks. Research in Comparative \& International Education, 10(1), 135-150. Doi: $10.1177 / 1745499914567823$

Wiles, J. and Bondi, J. (2007). Curriculum Development a Guide to Practice. Upper Saddle River: Pearson Printice Hall. 
UNIVERSITY OF CHITRAL JOURNAL OF LINGUISTICS AND LITERATURE

VOL. 5 | ISSUE I | JAN - JUNE | 2021 ISSN (E): 2663-1512, ISSN (P): 2617-3611

Wulandari, D. \& Murdiono, M. (2018). Peace Values on Pancasila and Civic Education Textbooks in Senior High School. Advances in Social Science, Education and Humanities Research, 251.

UNESCO. (1994). Recommendation Concerning Education for International Understanding, Cooperation and Peace and Education Relating to Human Rights and Fundamental Freedoms. Paris: Unesco. https://www.nsgt.org/promoting-peace-in-theclassroom/ Dr Maria Montessori

UNESCO. 1995. Declaration of Principles on Tolerance. Paris: UNESCO.

UNESCO. 2002. Learning to be: A holistic and integrated approach to values education for human development: Core values and the valuing process for developing innovative practices for values education toward international understanding and a culture of peace. Bangkok: UNESCO.

UN (United Nations). 1948. The Universal Declaration of Human Rights. Paris: UN.

UN (United Nations).1999. Declaration on a Culture of Peace. http://www.undocuments.net/a53r243a. htm.

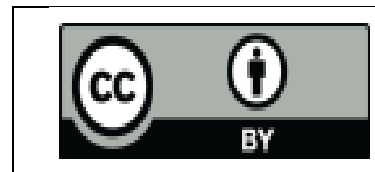

@ 2021 by the author. Licensee University of Chitral, Journal of Linguistics \& Literature, Pakistan. This article is an open access article distributed under the terms and conditions of the Creative Commons Attribution (CC BY) (http://creativecommons.org/licenses/by/4.0/). 